\title{
Protective role of wheat germ and its oil on some biochemical parameters in diabetic rats
}

\author{
Eman Fouad Mohamed; Ahmed Amin.; Eman,Gh, M. and Elham, \\ M.M \\ Nutrition and Food Science Department, Faculty of Home \\ Economic, Helwan University
}

\begin{abstract}
$\underline{\text { Abstract }}$
The aim of this study was to investigate the preventing effect of wheat germ and its oil individually at different dosages on some biochemical factors in diabetic rats. Animals were randomly divided into 6 groups (7 rats / group). Group (1) fed on basal diet (normal control group), group (2) fed on basal diet + alloxan (diabetic control group), group (3) fed on basal diet $+15 \%$ wheat germ (WG), group (4) fed on basal diet $+30 \%$ wheat germ (WG), group (5) fed on basal diet and $10 \%$ wheat germ oil (WGO), group (6) fed on basal diet and $20 \%$ wheat germ oil (WGO). Blood samples were collected, serum was separated for estimating urea, creatinine, cholesterol, HDL-c, LDL-c, VLDL-c, triglycerides (TG), AST and ALT. Results showed that all used dosages of wheat germ and wheat germ oil had significant reduction $(\mathrm{P}<0.05)$ in blood glucose levels in all groups. Also total lipid, triglycerides and VLDL-C decreased significantly in diabetic rats fed on basal either wheat germ or its oil at all tested levels as compared with the diabetic control group. Moreover, ALT concentration were decreased significantly in diabetic rats at the same trend compared with positive control groups. These findings suggest that wheat germ and wheat germ oil could be used as a supplement in some food products for helping diabetic patients and decreasing the risk of diabetes mellitus due to its beneficial effect on blood glucose levels.
\end{abstract}


Key words: Wheat germ, Wheat germ oil, Hyperglycemia , Total cholesterol , AST, ALT, Triglyceride , Uric acid, Urea nitrogen , Glucose.

\section{Introduction}

Wheat germ and its oil is excellent source of Vitamin E .Microvascular complications of diabetes share a common pathophysiology that may be explained as a direct or indirect consequence of hyperglycemia-mediated overproduction of reactive oxygen species. Microvascular deterioration is preventable either by the inhibition of superoxide accumulation or by modulating the blood glucose levels, and among several microvascular disorders, nephropathy can be improved by antioxidants (KedzioraKornatowska et al., 2003 also Kikkawa et al 2003 and Evans et al., 2002).

Fanny et al, (2008) assessed the effect of wheat germ supplementation, as a dietary source of vitamin E, on antioxidant protection in rat and reported that, wheat germ appears to be very effective to improve antioxidant defense status, especially in tissues, irrespective of modifications of lipids status. Jensen et al, (2004) suggest a lower risk of diabetes and heart disease in persons who consume diets high in whole grains or wheat germ. Wheat germ oil is an organic nutritionally rich vegetable oil. It is an excellent source of essential fatty acids (octacosanol, linoleic and linolenic). Wheat germ oil is one of nature's richest sources of polyunsaturates and vitamin $\mathrm{E}$ (Kahlon 1989). A study by Paranich et al, 2000 showned that in oral administration wheat germ oil efficiently saturates the body with vitamin E . Also Jonnala, et al., (2005) reported that, wheat germ oil has a number of other nutritional and health benefits factors like high content of vitamin $\mathrm{E}$ and phytosterol which may be the reason of its 
lowering effect on triglyceride. Thus the WGO would have reducing effect on triglyceride level.

Intake of whole grains is inversely associated with risk factor of diabetes and ischemic heart disease. The lower risk associated with whole-grain, bran, and germ intakes may be mediated through improvements in glycemic control, lipid profiles, or reduced inflammation( Jensen et al, 2006). The efficiency of cholesterol absorption from test meals was substantially lower after consumption of original wheat germ than after consumption of phytosterol-free wheat germ, which suggests that endogenous phytosterols in wheat germ and possibly in other low-fat vegetable foods may have important effects on cholesterol absorption and metabolism that are independent of major nutrients (Richard et al., 2003).

The present study was designed to examine the impact of wheat germ and wheat germ oil on some biochemical parameters in diabetes.

\section{Materials :}

\section{Materials and Methods}

Wheat germ and wheat germ oil were obtained from the Agricultural Reseach Center, Giza. Casein, cellulose, vitamins and minerals mixture were purchased from El- Gomhoria Company, Cairo, Egypt.

\section{Biological Study:}

Forty two male rats, four weeks old, weighing $95 \pm 0.84 \mathrm{~g}$ were used in the present study. Rats were obtained from the Institute of Ophthalmology, animal house department. Animals were housed individually in stainless steel cages, at room temperature given water 
at libitum and fed on basal diet for one week for an acclimization ; Basal diet was prepared according to Reeves et al., (1993).

Rats have taken alloxan at dose (185 $\mathrm{ml} /$ rat body weight ) for diabetes induction. Rats were divided into six groups, all groups have taken alloxan except group (1), each group contains seven rats as follows :

Group (1) : normal control .

Group (2) : diabetic control .

Group (3) : Fed on basal diet plus $15 \%$ wheat germ (WG).

Group (4) : Fed on basal diet plus 30\% wheat germ (WG).

Group (5) : Fed on basal diet plus 10\% wheat germ oil (WGO).

Group (6) : on basal diet plus $20 \%$ wheat germ oil (WGO).

Food intake was assessed daily while body weights were recorded weekly and percentage change in body weight was calculated. After 6 weeks period, rats were fasted over night then sacrificed under ether anesthesia. Blood was collected in a heparin containing tube and centrifuged at $3000 \mathrm{rpm}$ for $15 \mathrm{~min}$, and stored at $-20^{\circ} \mathrm{C}$ until analysis. Blood glucose concentration was determined according to ( Young, 2001), blood urea was determined according to(Patton and Crouch, 1977), creatinine was determined according to(Bohmer, 1971).

Total lipid was determined by the method of Schmit (1964) ; total cholesterol was determined using enzymatic method of Allain et al,(1974) ;triglyceride estimated according to the method of Wahlefeld (1974), HDL-C (Arcol, 1989) and LDL-C according to the method of (Sharf et al, 1985). Serum aspartate and alanine amino transferase enzymes (AST and AL T) were determined according to (Bergmeyer et al 1978). Liver, heart, kidney, spleen and lung were removed, cleaned and weighted, to calculate relative organs weight.

\section{$\underline{\text { Statistical analysis: }}$}


The obtained data were statistically analyzed according to the SPSS-PC statistical package software, version, 11.0 (SAS 1998). The results were expressed as means \pm SE. Data were analyzed by one way analysis of variance (ANOVA).

\section{$\underline{\text { Results and discussion }}$}

Table (1) showed initial, final weight and body weight gain \% of rats. The control + group revealed significant decrease in mean values of BWG \% (120.16 \pm 3.7$)$, compared with those of controlgroup (141.58 \pm 7.9 ). The reduction in BWG\% was observed in diabetic rats which agreed with the finding of the American Diabetes Association 2003. Also the data obtained cleared that BWG\% decreased significantly in diabetic rats fed on the WG or WGO at any concentration as compared with the positive control. Weight loss plays a positive role in the lowering blood glucose level in diabetics as demonstrated by AL-Shamsi et al ., 2004, also Greenberg et al., (2005) reported that, weight loss may contribute toward reducing the risk of diabetes.

Table (2) illustrated weight organs of all groups. It can be notice that liver weight increased significantly in diabetic rats fed on basal diet plus $30 \%$ wheat germ as compared with group fed on basal diet plus $15 \%$ wheat germ $(4.02 \pm 0.31,3.14 \pm 0.25$ respectively). Kidney weight increased significantly in diabetic rats fed on basal diet plus $30 \%$ wheat germ or $10 \%$ wheat oil $(0.74 \pm 0.04,0.72 \pm 0.09$, respectively) compared with the control or control (+) or group fed on basal diet plus $15 \%$ wheat germ $(0.54 \pm 0.09,0.53 \pm 0.03,0.58 \pm 0.03$ respectively). Spleen weight increased significantly in diabetic rats fed on basal diet plus $30 \%$ wheat germ or $20 \%$ weight germ oil $(0.23 \pm 0.03,0.22 \pm 0.02$ respectively) as compared with control $(+)$ $(0.15 \pm 0.01)$. Heart weight increased significantly in diabetic rats fed on basal diet plus $20 \%$ wheat germ oil as compared with diabetic group fed on basal diet plus $15 \%$ wheat germ or control (+) or control. Whereas lung weight not affected significantly in all groups. 
The effect of wheat germ and wheat germ oils on serum glucose levels $(\mathrm{mg} / \mathrm{dl})$ in diabetic rats are presented in table (3). Untreated diabetic rats revealed a highly significant increase in the mean value of serum glucose $(183.8 \pm 2.7) \mathrm{mg} / \mathrm{dl}$ compared with the healthy normal rats $(84.4 \pm 2.7) \mathrm{mg} / \mathrm{dl}$. It is observed that the used all dosages of wheat germ and wheat germ oil had significant decreased $(\mathrm{P}<0.05)$ in blood glucose levels in all tested groups a compared with the diabetic control group. Our results are supported by those obtained by (Boros et al., 2001). It was reported that, wheat germ extract treatment is likely associated with the phosphorylation and transcriptional regulation of metabolic enzymes that are involved in glucose carbon redistribution between cell proliferation-related structural and functional macromolecules (RNA, DNA) and the direct oxidative degradation of glucose, which have devastating consequences for the proliferation and survival of pancreatic adenocarcinoma cells in culture.

Total lipid, triglycerides and very low density lipoprotein cholesterol (VLDL-C) are shown in table (3). Data revealed significant reduction in these parameters in diabetic rats fed on basal diet plus $15 \%$ wheat germ or $30 \%$ wheat germ or $10 \%$ wheat germ oil or $20 \%$ germ oil as compared with positive control. Serum cholesterol and low density lipoprotein (LDL-C) decreased significantly in diabetic rats fed on basal diet plus $30 \%$ wheat germ or $10 \%$ wheat germ oil or $20 \%$ germ oil as compared with positive control. From the above mentioned data, it could be concluded that, all tested groups which fed on WG or WGO at any level improved lipid fractions in diabetic rats, which is could be due to its antioxidant function and/or its direct regulatory effect on cell adhesion (Thomas et al., 1999).

In this respect Ostlund et al., (2003) reported that, the efficiency of cholesterol absorption was substantially lower after consumption of original wheat germ, which suggests that endogenous phytosterols in wheat germ may have important effects on cholesterol 
absorption and metabolism that are independent of major nutrients. It was appeared also that the absorption of labeled triacylglycerol and cholesterol were both delayed and reduced by wheat germ in part as a result of the inhibition of pancreatic lipase and the reduction in triacylglycerol lipolysis (Borel et al., 1989), this could be due to the fact that wheat germ oil in addition to vitamin E contains the other plant materials such as phytosterols which have estrogenic activity and can alter cholesterol metabolism or inhibit the enzymes involved in the synthesis of steroid hormones, which may affect the mechanisms of the hormone secretion (Soleimani et al., 2007). Thus the reducing effect of wheat germ and wheat germ oil on triglyceride and VLDL-C level is a positive finding of this study.

Whereas high density lipoprotein cholesterol (HDL-C) increased significantly in diabetic rats fed on basal diet plus $10 \%$ wheat germ oil or $20 \%$ germ oil compared with the positive control. These results indicate that wheat germ and wheat germ oil have beneficial effects on blood lipid profiles.

Table (4) presented the results of Aspartate Amine Transferase (AST) and Alanine Amine Transferase (ALT). Diabetic rats (control+) showed significant increase in ALT 47 \pm 1.14 enzyme level compared with the healthy rats (control-) with mean value levels 42.2 \pm 1.06 although an increase in the activity of ALT is a remarkable indication of liver complication (Soleimani et al., 2007). Also the same table showed that ALT levels were decreased significantly in diabetic rats fed on basal diet plus $15 \%$ wheat germ or $30 \%$ wheat germ or $10 \%$ wheat germ oil or $20 \%$ wheat germ oil as compared with positive control which may be due to the antioxidant effect of vitamin $\mathrm{E}$ content of the wheat germ oil as stated by Bansal et al, 2005 in the same table revealed that AST, creatinine or urea not decreased significantly in diabetic rats fed on basal diet plus $15 \%$ wheat germ or $30 \%$ wheat germ or $10 \%$ wheat germ oil or $20 \%$ germ oil compared with the positive control. Therefore, it can be concluded that wheat 
germ and wheat germ oil is attenuate the inflammations of diabetes and protect its related complications.

The present results indicated that wheat germ and wheat germ oil play a beneficial role in reduces blood lipid parameters and blood glucose level. Therefore, our study suggested that wheat germ and wheat germ oil could be used as a supplement in some food products for diabetic patients.

\section{References}

Allain, C.C; Poom, I.S; Chran, C.S.G; Richmond, W and Fu, P.C. (1974): Enzymatic determantion total serum cholesterol. Chem.20.(4) 420-25.

AL-Shamsi, M. S.; Amin, A. and Adeghate, E. (2004): Beneficial effect of vitamin $\mathrm{E}$ on metabolic parameters of diabetic rats. Molecular Cell. Biochem., 261(1):35-42.

American Diabetes Association (2003): Report of the Expert Committee on the Diagnosis and lassification of Diabetes Mellitus (Clinical Practice recommendations 2002). Diabetes Carte, 25 (Suppl.1): 5-20.

Arcol, I SIl, (1989): Separation or high density lipoproteins and determination of cho!estelrol and phuspholipids bound to these fraction, Biomcricu. (I), 121-26.

Bansal, A.K., M. Bansal, G. Soni and D. Bhatnagar, (2005): 
Protective role of vitamin $\mathrm{E}$ pre-treatment on $\mathrm{N}$ nitrosodiethylamine induced oxidative stress in rat liver. Chem. Biol. Interact 20; 156: 101-111.

Bergmeyer, H.U.; Schreiber, P. and Wahlefeld, A.W. (1978): Optimization of methods for aspartate aminotransferase and alanine aminotrasferase. Clin.Chem., 24, 58-61.

Bohmer, H.B.V.M. (1971): Micro-determination of creatinine. Clin. Chem. Acta; 32:.81-85.

Borel, P. ; Lairon,D.; Senft, M.; Chautan, M. and Lafont, H. (1989): Wheat bran and wheat germ: effect on digestion and intestinal absorption of dietary lipids in the rat. American Journal of Clinical Nutrition, Vol 49, 1192-1202.

Boros, L. G.; Lapis, K.; Szende, B.; Tomoskozi-Farkas, R.; Balogh, A.; Boren, J .S.; Marin, S.; Cascante, M. S.; Hidvegi, M. (2001): Wheat Germ Extract Decreases Glucose Uptake and RNA Ribose Formation but Increases Fatty Acid Synthesis in MIA Pancreatic Adenocarcinoma Cells. Pancreas. 23(2):141-147.

Evans, J.L.; Goldfine, I.D.; Maddux, B.A.; Grodsky, G.M. (2002): Oxidative stress and stress-activated signaling pathways: a unifying hypothesis of type 2 diabetes. Endocr Rev.;23:599622.

Fanny, L.; Anthony, F. ;Bernard, L.; Elyett,G.; Edmond, R.; Andrzej, M.; Elisabeth, C. and Christian, D. (2008): Wheat Germ Supplementation of a Low Vitamin E Diet in Rats Affords Effective Antioxidant Protection in Tissues.

Greenberg, J.A.; Axen, K.V.; Schnoll, R. and Boozer, C.N. (2005): Coffee, tea and diabetes: the role of weight loss and caffeine. Int J Obes Relat Metab Disord;29:1121-9.

Jensen, M. K; Koh-Banerjee, P; Frank, B. Hu; Franz, M.; Sampson, L.; Grønbæk, M. and Rimm, E.B. (2004): Intakes of whole grains, bran, and germ and the risk of coronary heart disease in men Am. J. Clinical Nutrition, Vol. 80(6)492-1499.

Jensen, M. K; Koh-Banerjee, P; Franz, M.; Sampson, L. ; 
Grønbæk, M. and Rimm, E.B. (2006): Whole grains, bran, and germ in relation to homocysteine and markers of glycemic control, lipids, and inflammation. American Journal of Clinical Nutrition, Vol. 83, No. 2, 275-283.

Jonnala, R.S., Dunford, N.T. and Irmak, S. (2005): Policosanol, tocopherol and phytosterol composition of wheat extract. IFT Annual Meeting, July 15-20, New Orleans Louisiana, 54G-1.

Kahlon, T.S. (1989): Nutritional implications and uses of wheat and oat kernel oil. Cereal foods world (USA), v. 34(10) Oct p. 872-875.

Kedziora-Kornatowska， K.; Szram, S.; Kornatowski, T.; Szadujkis-Szadurski, L.; Kedziora, J., and Bartosz, G. (2003): Effect of vitamin $E$ and vitamin $C$ supplementation on antioxidative state and renal glomerular basement membrane thickness in diabetic kidney. Nephron Exp Nephrol.;95:E13443.

Kikkawa, R.; Koya, D. and Haneda, M. (2003): Progression of diabetic nephropathy. Am J Kidney Dis.;41:S19-21.

Ostlund, R. E. ; Racette, S. B. and Stenson, W. F. (2003): Inhibition of cholesterol absorption by phytosterol-replete wheat germ compared with phytosterol-depleted wheat germ. Am.-J. of clinical Nutrition. 77 (6): 1385-1389.

Paranich, V.A.; Cherevko, O.I. and Frolova, N.A. (2000): The effect of wheat germ oil on the antioxidant system of animals. Mar;(2):40-4.

Patton, C. J. and Crouch, S. R. (1977) : Enzymatic colorometeric method to determine urea in serum. Anal.Chem.; 49-464.

Reeves, P.; Nielsen, F. and Fahmy, G. (1993): "Reported of the American Institute of Nutrition; committee on the reformulation of the AIN76, A rodent diet". J. Nutrition, 123:1939-51.

Richard, E. O.; Susan, B. R. and William, F. S. (2003): Inhibition of cholesterol absorption by phytosterol-replete wheat germ compared with phytosterol-depleted wheat germ. American 
Journal of Clinical Nutrition, Vol. 77, No. 6, 1385-1389.

SAS (1998): Statistical Analysis System, SAS User's Guide: Statistics, SAS Institute Inc. Editors, Cary, NC.

Sharf,M; Oettinger, M; Lanir, A; Kahana, L. ami Yeshurun, D. (1985): Lipid and lipoprotein levels following pure estradiol implantation in postmenopausal women. Gynecol. Obstet. lnvest.; 19: 207-12.

Schmit, 1. M. (1964): Colorimetric determination of total lipids with sulfphophosph vanillic mixture. Thesis, Lyon.

Soleimani, M.M.; Abnosi, M.H. Naderi, A.and Mahmodi M. (2007): Preventing Effects Wheat Germ Oil on Sex Hormones, Liver Enzymes, Lipids and Proteins in Rat Serum Following Treatment with p-Nonylphenol. Journal of Biological Sciences 7 (8): 1406-1411.

Thomas, H.; Seppo, Y. H.; Elke, W.; Jukka, L. and Helmut, D. (1999): Effect of vitamin $\mathrm{E}$ on endothelial vasodilator function in patients with hypercholesterolemia, chronic smoking or both. J Am Coll Cardiol, 33:499-505.

Wahlefeld, A.W. (1974): In "Methods of Enzymatic Analysis", Academic Press, Chapter 5, Page 1831- 1835.

Young, D. S. (2001): Effects of drugs on clinical laboratory tests. AACC press Washington D. C. 
Table ( 1 ) : Effect of different doses of wheat germ and wheat germ oil on body weight gain (Mean \pm SE).

\begin{tabular}{|c|c|c|c|c|}
\hline $\begin{array}{r}\text { Rar: } \\
\text { G }\end{array}$ & leters & $\begin{array}{c}\text { initial weight } \\
\text { (g) }\end{array}$ & $\begin{array}{c}\text { final weight } \\
\text { (g) }\end{array}$ & $\begin{array}{c}\text { Body } \\
\text { weight } \\
\text { gain\% } \\
\text { (BWG\%) }\end{array}$ \\
\hline Norm & $\begin{array}{l}\text { Control } \\
\text { ) }\end{array}$ & $\begin{array}{c}82.4 \\
\pm 1.1^{b}\end{array}$ & $\begin{array}{l}199.0 \\
\pm 6.4^{a}\end{array}$ & $\begin{array}{c}141.58 \\
\pm 7.9^{\mathrm{a}}\end{array}$ \\
\hline Diabet & $\begin{array}{l}\text { Control } \\
\text { ) }\end{array}$ & $\begin{array}{l}97.0 \\
\pm 4.6^{a}\end{array}$ & $\begin{array}{l}212.0 \\
\pm 7.5^{\mathrm{a}}\end{array}$ & $\begin{array}{r}120.16 \\
\pm 3.7^{b}\end{array}$ \\
\hline$\ddot{\Xi} \Xi$ & $\begin{array}{l}\text { WG } \\
15 \%\end{array}$ & $\begin{array}{l}95.0 \\
\pm 4.7^{\text {a }} \\
\end{array}$ & $\begin{array}{l}196.0 \\
\pm 9.7^{\text {a }} \\
\end{array}$ & $\begin{array}{r}107.39 \\
\pm 2.5^{c} \\
\end{array}$ \\
\hline$\sum \sum$ & $\begin{array}{l}\text { WG } \\
30 \%\end{array}$ & $\begin{array}{l}96.0 \\
\pm 4.3^{a} \\
\end{array}$ & $\begin{array}{c}152.0 \\
\pm 13.0\end{array}$ & $\begin{array}{c}58.64 \\
\pm 14.0\end{array}$ \\
\hline 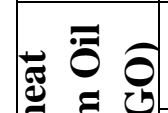 & $\begin{array}{l}\text { WG O } \\
10 \%\end{array}$ & $\begin{array}{l}103.0 \\
\pm 3.4^{a} \\
\end{array}$ & $\begin{array}{l}162.0 \\
\pm 2.5^{b c} \\
\end{array}$ & $\begin{array}{l}58.23 \\
\pm 4.7^{\mathrm{e}} \\
\end{array}$ \\
\hline 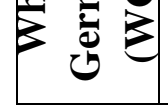 & $\begin{array}{l}\text { WGO } \\
20 \% \\
\end{array}$ & $\begin{array}{l}97.0 \\
\pm 4.6^{a} \\
\end{array}$ & $\begin{array}{l}186.0 \\
\pm 8.7^{\text {ab }} \\
\end{array}$ & $\begin{array}{l}91.77 \\
\pm 4.7^{d} \\
\end{array}$ \\
\hline
\end{tabular}

Values are expressed as means $\pm \mathrm{SE}$.

Differences at $\mathbf{p}<\mathbf{0 . 0 5}$.

Means with the same letters in each column are insignificantly different . 
Table (2): Mean values of relative organs weight of experimental rats.

\begin{tabular}{|c|c|c|c|c|c|c|}
\hline \multicolumn{2}{|c|}{ Parameters } & $\begin{array}{l}\text { Liver } \\
\text { (g) }\end{array}$ & $\begin{array}{l}\text { Kidney } \\
\text { (g) }\end{array}$ & $\begin{array}{c}\text { Spleen } \\
(\mathrm{g})\end{array}$ & $\begin{array}{l}\text { Heart } \\
\text { (g) }\end{array}$ & $\begin{array}{l}\text { Lung } \\
\text { (g) }\end{array}$ \\
\hline \multicolumn{2}{|c|}{$\begin{array}{c}\text { Normal } \\
\text { Control } \\
(-) \\
\end{array}$} & $\begin{array}{c}3.91 \\
\pm 0.23 \\
\text { ab }\end{array}$ & $\begin{array}{c}0.54 \\
\pm 0.09^{b}\end{array}$ & $\begin{array}{c}0.19 \\
\pm 0.02^{\text {ab }}\end{array}$ & $\begin{array}{c}0.29 \\
\pm 0.02^{c}\end{array}$ & $\begin{array}{c}0.53 \\
\pm 0.04 \\
\quad \text { a }\end{array}$ \\
\hline \multicolumn{2}{|c|}{$\begin{array}{c}\text { Diabetic } \\
\text { Control (+) }\end{array}$} & $\begin{array}{c}3.70 \\
\pm 0.28 \\
\text { ab }\end{array}$ & $\begin{array}{c}0.53 \\
\pm 0.03 \\
\text { b }\end{array}$ & $\begin{array}{c}0.15 \\
\pm 0.01^{b}\end{array}$ & $\begin{array}{c}0.35 \\
\pm 0.02\end{array}$ & $\begin{array}{l}0.52 \\
\pm 0.06 \\
\quad \mathrm{a}\end{array}$ \\
\hline \multirow{2}{*}{ 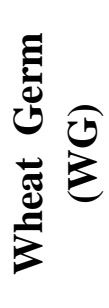 } & $\begin{array}{l}\text { WG } \\
15 \%\end{array}$ & $\begin{array}{c}3.14 \\
\pm 0.25^{b}\end{array}$ & $\begin{array}{c}0.58 \\
\pm 0.03\end{array}$ & $\begin{array}{c}0.19 \\
\pm 0.02^{\text {ab }}\end{array}$ & $\begin{array}{c}0.38 \\
\pm 0.02^{b}\end{array}$ & $\begin{array}{r}0.52 \\
\pm 0.06^{a}\end{array}$ \\
\hline & $\begin{array}{l}\text { WG } \\
30 \%\end{array}$ & $\begin{array}{r}4.02 \\
\pm 0.31^{a}\end{array}$ & $\begin{array}{c}0.74 \\
\pm 0.04^{a}\end{array}$ & $\begin{array}{c}0.23 \\
\pm 0.03\end{array}$ & $\begin{array}{c}0.41 \\
\pm 0.04^{\text {ab }}\end{array}$ & $\begin{array}{c}\mathbf{0 . 6 3} \\
\pm \mathbf{0 . 0 7} \\
\quad \mathrm{a}\end{array}$ \\
\hline \multirow{2}{*}{ 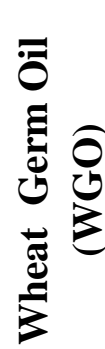 } & $\begin{array}{l}\text { WG O } \\
10 \%\end{array}$ & $\begin{array}{c}3.59 \\
\pm 0.21 \\
\text { ab }\end{array}$ & $\begin{array}{c}0.72 \\
\pm 0.09^{a}\end{array}$ & $\begin{array}{c}0.21 \\
\pm 0.02\end{array}$ & $\begin{array}{c}0.41 \\
\pm 0.02^{\text {ab }}\end{array}$ & $\begin{array}{c}0.52 \\
\mathbf{+ 0 . 0 7} \\
\quad \mathrm{a}\end{array}$ \\
\hline & $\begin{array}{l}\text { WGO } \\
20 \%\end{array}$ & $\begin{array}{c}3.44 \\
\pm 0.28 \\
\text { ab }\end{array}$ & $\begin{array}{c}0.66 \\
\pm 0.1^{\text {ab }}\end{array}$ & $\begin{array}{c}0.22 \\
\pm 0.02\end{array}$ & $\begin{array}{c}0.46 \\
\pm 0.02\end{array}$ & $\begin{array}{l}0.55 \\
\pm 0.02 \\
\quad \text { a }\end{array}$ \\
\hline
\end{tabular}


Values are expressed as means $\pm \mathrm{SE}$.

Differences at $\mathrm{p}<0.05$.

Means with the same letters in each column are insignificantly different .

Table (3): Effect of wheat germ and wheat germ oil on serum glucose levels $(\mathrm{mg} / \mathrm{dl})$ and lipid fractions in diabetic rats.

\begin{tabular}{|c|c|c|c|c|c|c|c|c|}
\hline \multicolumn{2}{|c|}{$\begin{array}{c}\text { Paramete } \\
\text { Groups }\end{array}$} & $\begin{array}{c}\text { Gluco } \\
\text { se(mg } \\
\text { /dl) }\end{array}$ & $\begin{array}{c}\text { T.Lip } \\
\text { id } \\
(\mathbf{m g} / \mathbf{d} \\
\text { l) }\end{array}$ & $\begin{array}{c}\text { Choleste } \\
\text { rol } \\
(\mathbf{m g} / \mathbf{d l})\end{array}$ & $\begin{array}{c}\text { TG } \\
(\mathbf{m g} / \mathbf{d} \\
\text { l) }\end{array}$ & $\begin{array}{c}\text { HDL- } \\
\text { C } \\
(\mathrm{mg} / \mathrm{d} \\
\mathrm{l})\end{array}$ & $\begin{array}{l}\text { LDL- } \\
\text { C } \\
(\mathrm{mg} / \\
\text { dl) }\end{array}$ & $\begin{array}{c}\text { VLD } \\
\text { L-C } \\
(\mathrm{mg} / \mathrm{d} \\
\mathrm{l})\end{array}$ \\
\hline \multicolumn{2}{|c|}{$\begin{array}{c}\text { Normal } \\
\text { Control } \\
(-)\end{array}$} & $\begin{array}{r}84.4^{d} \\
\pm 2.7^{d}\end{array}$ & $\begin{array}{l}263.8 \\
\pm 6.9^{d}\end{array}$ & $\begin{array}{c}109.8 \\
\pm 4.85^{d}\end{array}$ & $\begin{array}{c}87.0 \\
\pm \mathbf{3 . 1 3} \\
\mathrm{b}\end{array}$ & $\begin{array}{c}47.2 \\
\pm 4.13 \\
\mathrm{a}\end{array}$ & $\begin{array}{c}45.2 \\
\pm 8.6^{d}\end{array}$ & $\begin{array}{c}17.4 \\
\pm 0.6^{b}\end{array}$ \\
\hline \multicolumn{2}{|c|}{$\begin{array}{c}\text { Diabetic } \\
\text { Control } \\
(+)\end{array}$} & $\begin{array}{r}183.8 \\
\pm 2.7^{\text {a }}\end{array}$ & $\begin{array}{r}416.4 \\
\pm 2.2^{\mathrm{a}}\end{array}$ & $\begin{array}{c}173.0 \\
\pm 3.94^{\mathrm{a}}\end{array}$ & $\begin{array}{r}102.2 \\
\pm 2.8^{a}\end{array}$ & $\begin{array}{c}24.8 \\
\pm 2.03 \\
c\end{array}$ & $\begin{array}{r}127.7 \\
\pm 5.8^{\mathrm{a}}\end{array}$ & $\begin{array}{r}20.44 \\
\pm 0.6^{a}\end{array}$ \\
\hline \multirow{2}{*}{ | } & $\begin{array}{l}\text { WG } \\
15 \%\end{array}$ & $\begin{array}{r}170.0 \\
\pm 1.3^{\mathrm{b}}\end{array}$ & $\begin{array}{l}381.6 \\
\pm 1.6^{b}\end{array}$ & $\begin{array}{c}166.4 \\
\pm 1.89^{\mathrm{a}}\end{array}$ & $\begin{array}{r}73.0 \\
\pm 1.41 \\
\mathrm{c}\end{array}$ & $\begin{array}{c}30.2 \\
\pm 3.6^{b c} \\
\text { b }\end{array}$ & $\begin{array}{r}121.6 \\
\pm 4.8^{\mathrm{a}}\end{array}$ & $\begin{array}{r}14.6 \\
\pm 0.3^{c}\end{array}$ \\
\hline & $\begin{array}{l}\text { WG } \\
\text { 30\% }\end{array}$ & $\begin{array}{r}148.6 \\
\pm 1.6^{c}\end{array}$ & $\begin{array}{r}310.0 \\
\pm 2.1^{\mathrm{c}}\end{array}$ & $\begin{array}{c}147.6 \\
\pm 2.56\end{array}$ & $\begin{array}{c}66.0 \\
\pm 1.87 \\
\text { cd }\end{array}$ & $\begin{array}{c}32.8 \\
\pm 2.52 \\
\text { bc }\end{array}$ & $\begin{array}{r}101.6 \\
\pm 2.2^{b}\end{array}$ & $\begin{array}{c}13.2 \\
\pm 0.4^{\mathrm{c}}\end{array}$ \\
\hline $\begin{array}{l}\overline{0} \\
\tilde{z} \\
\tilde{\nu} \\
\end{array}$ & $\begin{array}{c}\text { WG } \\
\text { O } \\
10 \%\end{array}$ & $\begin{array}{r}145.2 \\
\pm 1.7^{\mathrm{c}}\end{array}$ & $\begin{array}{r}306.8 \\
\pm 1.9^{\mathrm{c}}\end{array}$ & $\begin{array}{c}144.8 \\
\pm 1.71^{b}\end{array}$ & $\begin{array}{c}65.8 \\
\pm 2.08 \\
\text { cd }\end{array}$ & $\begin{array}{c}37.4 \\
\pm 4.3^{\text {ab }}\end{array}$ & $\begin{array}{c}94.24 \\
\pm 5.7 \\
\text { bc }\end{array}$ & $\begin{array}{c}13.16 \\
\pm 0.4 \\
\text { cd }\end{array}$ \\
\hline
\end{tabular}




\begin{tabular}{|c|c|c|c|c|c|c|c|}
\hline $\begin{array}{c}\text { WG } \\
\text { O } \\
20 \%\end{array}$ & $\begin{array}{r}143.2 \\
\pm 0.8^{\mathrm{c}}\end{array}$ & $\begin{array}{r}303.0 \\
\pm 2.0^{c}\end{array}$ & $\begin{array}{r}135.0 \\
\pm 3.16^{c}\end{array}$ & $\begin{array}{r}63.6 \\
\pm 2.62 \\
\mathrm{~d}\end{array}$ & $\begin{array}{c}39.6 \\
\pm 4.11 \\
\text { ab }\end{array}$ & $\begin{array}{l}82.68 \\
\pm 5.7^{\mathrm{c}}\end{array}$ & $\begin{array}{l}12.72 \\
\pm 0.5^{d}\end{array}$ \\
\hline
\end{tabular}

Values are expressed as means $\pm \mathrm{SE}$. $\quad$ Differences at $\mathrm{p}<0.05$.

Means with the same letters in each column are insignificantly different .

Table (4): Effect of wheat germ and wheat germ oil on

liver and kidneys function of diabetic rats

\begin{tabular}{|c|c|c|c|c|c|}
\hline \multicolumn{2}{|c|}{ Parameters } & $\begin{array}{c}\text { ALT } \\
(\mathbf{u} / \mathbf{m l})\end{array}$ & $\begin{array}{c}\text { AST } \\
(\mathbf{u} / \mathbf{m l})\end{array}$ & $\begin{array}{c}\text { Creatinin } \\
\text { e } \\
(\mathbf{m g} / \mathbf{d l})\end{array}$ & $\begin{array}{c}\text { Urea } \\
(\mathrm{mg} / \mathrm{dl})\end{array}$ \\
\hline \multicolumn{2}{|c|}{$\begin{array}{c}\text { Normal Control } \\
(-)\end{array}$} & $\begin{array}{c}42.2 \\
\pm 1.06^{b}\end{array}$ & $\begin{array}{r}73.8 \\
\pm 2.05^{a}\end{array}$ & $\begin{array}{c}1.08 \\
\pm 0.19^{a}\end{array}$ & $\begin{array}{c}25.4 \\
\pm 1.36^{\mathrm{a}}\end{array}$ \\
\hline \multicolumn{2}{|c|}{$\begin{array}{c}\text { Diabetic Control } \\
(+)\end{array}$} & $\begin{array}{c}47.0 \\
\pm 1.14^{\mathrm{a}}\end{array}$ & $\begin{array}{c}70.4 \\
\pm 0,74^{\mathrm{a}}\end{array}$ & $\begin{array}{c}1.24 \\
\pm 0.17^{\mathrm{a}}\end{array}$ & $\begin{array}{c}25.4 \\
\pm 1.91^{\mathrm{a}}\end{array}$ \\
\hline \multirow{2}{*}{ 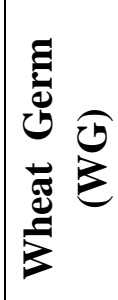 } & $\begin{array}{l}\text { WG } \\
15 \%\end{array}$ & $\begin{array}{c}39.8 \\
\pm 1.01^{\mathrm{bc}}\end{array}$ & $\begin{array}{c}69.0 \\
\pm 2.54^{\mathrm{a}}\end{array}$ & $\begin{array}{c}1.11 \\
\pm 0.08\end{array}$ & $\begin{array}{c}24.0 \\
\pm 1.81^{\mathrm{a}}\end{array}$ \\
\hline & $\begin{array}{l}\text { WG } \\
\mathbf{3 0 \%}\end{array}$ & $\begin{array}{c}35.2 \\
\pm 1.35^{d}\end{array}$ & $\begin{array}{l}70.4 \\
\pm 2.4^{\mathrm{a}}\end{array}$ & $\begin{array}{c}1.01 \\
\pm 0.05^{a}\end{array}$ & $\begin{array}{c}22.6 \\
\pm 2.90^{\text {a }}\end{array}$ \\
\hline \multirow{2}{*}{ 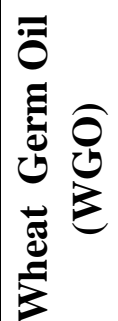 } & $\begin{array}{c}\text { WG O } \\
10 \%\end{array}$ & $\begin{array}{c}36.8 \\
\pm 1.82^{\text {cd }}\end{array}$ & $\begin{array}{c}69.4 \\
\pm 1.20^{\mathrm{a}}\end{array}$ & $\begin{array}{c}0.99 \\
\pm 0.01^{\mathrm{a}}\end{array}$ & $\begin{array}{r}24.6 \\
\pm 1.07^{\text {a }}\end{array}$ \\
\hline & $\begin{array}{l}\text { WGO } \\
20 \%\end{array}$ & $\begin{array}{c}35.6 \\
\pm 1.16^{d}\end{array}$ & $\begin{array}{c}69.2 \\
\pm 3.21^{\mathrm{a}}\end{array}$ & $\begin{array}{c}0.94 \\
\pm 0.02^{a}\end{array}$ & $\begin{array}{r}26.6 \\
\pm 1.02^{\text {a }}\end{array}$ \\
\hline
\end{tabular}


Values are expressed as means $\pm \mathrm{SE}$.

Differences at $\mathbf{p}<\mathbf{0 . 0 5}$.

Means with the same letters in each column are insignificantly different

الدور الوقائى لجنين القمح وزيته على بعض المؤثرات البيوكيميائية فى الجرذان

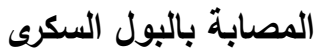

د ايمان فؤاد محمد -ــ أحمد على أمين -د إيمان مقبل غلاب- دـ إلهام محمد

$$
\text { محمود }
$$

قسم التظذية وعلوم الأطعمة - كلية الاقتصاد

$$
\text { المنزلي - جامعة حلوان. }
$$

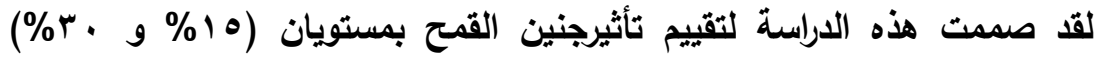

وكذلك زيت جنين القـح بمستويان (•l\% و •r\%) علي مستوى الجلوكوز فى الام و

صورة ليبيدات الدم وكذلك وظائف كلا من الكلى والكبد في الفئران الطبيعية و المصابة بداء البول السكرى. واستخدم في هذه التجرية 40 فأر من ذكور الفئران قسمت الى ست مجموعات احدهم مجموعة ضابطة سلبية و أخرى مجموعة ضابطة موجبة أي مصابة بالسكرى و باقي المجموعات تم تغذيتها وأمدادها بالجرعات المختلفة من جنين القمح أو زيته لمدة 7 أسابيع ثم بعدها تجميع مصل الام لتقدير السكر وصورة ليبيدات الام وظائف كلا من الكلى والكبد بها. وقد أظهرت النتائج من خلال التجرية البيولوجية والتحليل الكيميائي أن جميع التركيزات التى استخدمت فى التجرية قد أحلثت انخفاضا معنويا فى مستوى الجلوكوز فى السيرم مقارنة بالمجموعة الضابطة الموجبة وأيضا بالنسبة لليبيدات الام حدث انخفاض معنوي في كل من الكوليستيرول والليبيدات الكلية Total lipid) 
والجلسيريدات الثلاثية (TG) واللييويروتنيات المنخفضة الكثافة جلا (VLDL). كما

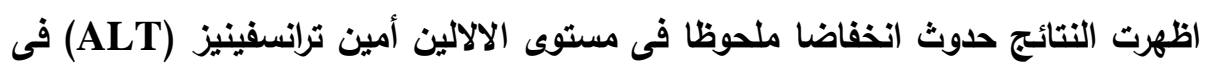
الدم فى كل المجموعات التى تم أمدادها بالجرعات المختلفة من جنين القمح و زيته بالمقارنة بالمجموعة الضابطة الموجبة ، ومما سبق فان الدراسة توصى بتدعيم الوجبات

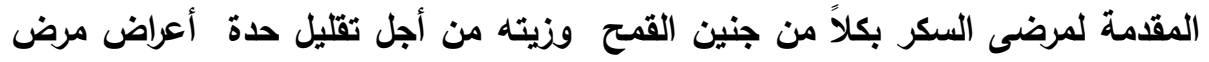
السكر لما له من تأثير جيد علي خفض مستويات السكر والدهون بالام. 